Historia Slavorum Occidentis

2021, nr $1(28)$

ISSN 2084-1213

DOI: $10.15804 /$ hso210101

DARIUSZ BŁASZCZYK (WARSZAWA)

Alicja Drozd-Lipińska (Toruń)

Andrzej Krzyszowski (Poznań)

Dariusz Poliński (TORUŃ)

Anna Wrzesińska (Lednica)

JACEK WrZesiński (Grzybowo)

\title{
Dieta elit państwa wczesnopiastowskiego w świetle badań izotopowych
}

Słowa kluczowe: dieta, państwo wczesnopiastowskie, badania izotopowe, groby komorowe

Keywords: diet, the early Piast state, isotope analyses, chamber graves

Abstract: This study presents and discusses the results of stable carbon and nitrogen isotopes analysis of individuals belonging to the social elites buried in chamber graves from the area of the first Piast state (the $2^{\text {nd }}$ half of the 10 th and the 1 st half of the $11^{\text {th }} \mathrm{c}$.).

\section{Wprowadzenie}

Jednym ze wskaźników pozycji społecznej jest dieta. $Z$ reguly nie jest ona identyczna dla całej populacji i może być determinowana przez różne czynniki środowiskowe i społeczne. Należą do nich: obszar zamieszkania, dostępność do danego pożywienia, jego dostępność w danym sezonie, zwyczaje kulturowe, nakazy i zakazy religijne, 
płeć i wiek, status społeczny oraz specyficzny sposób życia. Związek sposobu odżywiania się ze statusem społecznym opiera się przede wszystkim na tym, że pewne rodzaje pokarmu, takie jak np. mięso i inne produkty zwierzęce, są bardziej odżywcze i bardziej cenione od innych, a dostęp do nich nie jest równy dla wszystkich ${ }^{1}$.

Istnieją dwa główne sposoby rekonstrukcji diety dawnych społeczeństw oparte na metodach pośrednich i bezpośrednich. Metody pośrednie opierają się na wykorzystaniu informacji dostarczanych przez dane archeologiczne (pozyskiwane w czasie wykopalisk szczątki roślinne i zwierzęce) oraz pisane przekazy historyczne. Uzyskiwane na podstawie tych danych informacje pozwalają określić raczej potencjalne możliwości żywieniowe, a nie faktyczną dietę poszczególnych osób i grup ludzkich. Metody bezpośrednie wykorzystują rozwinięte w ostatnim czasie analizy biochemiczne kości ludzkich oparte na badaniach trwałych izotopów. Do tego typu badań wykorzystuje się izotopy azotu i węgla, których skład w kościach zależy od rodzaju spożywanego pożywienia zgodnie z zasadą, że człowiek jest tym, co je. Umożliwiają one, do pewnego stopnia, zrekonstruowanie diety konkretnych ludzi i całych populacji ${ }^{2}$.

Niniejsze studium prezentuje i omawia wyniki badań, których celem było określenie na podstawie badania trwałych izotopów węgla i azotu diety osób chowanych w uważanych za elitarne grobach komorowych z obszaru państwa pierwszych Piastów. Przeprowadzone badania miały na celu stwierdzenie, co spożywali ludzie pochowani w tego typu grobach, czy ich dieta różniła się od innych przedstawicieli populacji oraz czy pożywienie mężczyzn i kobiet chowanych w grobach komorowych było podobne, czy różne. Próbki do badań zostały pobrane z wybranych szkieletów osób pochowanych na cmentarzyskach w Bodzi, Dziekanowicach i Pniu. Zostały one wykonane w ramach realizacji projektu badawczego „Swoi czy obcy? Pochówki w grobach komorowych na ziemiach polskich w okresie wczesnego średniowiecza”. Dodatkowo zostały wzięte pod uwagę opublikowane wyniki badań diety osób z grobów komorowych z Kałdusa, przeprowadzone przez Laurie Reitsema ${ }^{3}$ (ryc. 1).

1 S. Mays, The archaeology of human bones, London-New York 2010; L.J. Reitsema, T. Kozłowski, D.E. Crews, M.A. Katzenberg, W. Chudziak, Resiliance and local dietary adaptation in rural Poland, 1000-1400 CE, Journal of Anthropological Archaeology 45 (2017), s. 38-52.

2 B. Mnich, A. Lisowska-Gaczorek, K. Szostek, Dieta mieszkańców Radomia na przestrzeni ostatniego milenium, [w:] Bioarcheologiczne badania populacji ludzkiej z Radomia od XI do XIX wieku, red. J. Tomczyk, Warszawa 2018, s. 129-142.

3 L.J. Reitsema, T. Kozłowski, D.E. Crews, M.A. Katzenberg, W. Chudziak, Resiliance, s. 38-52. 


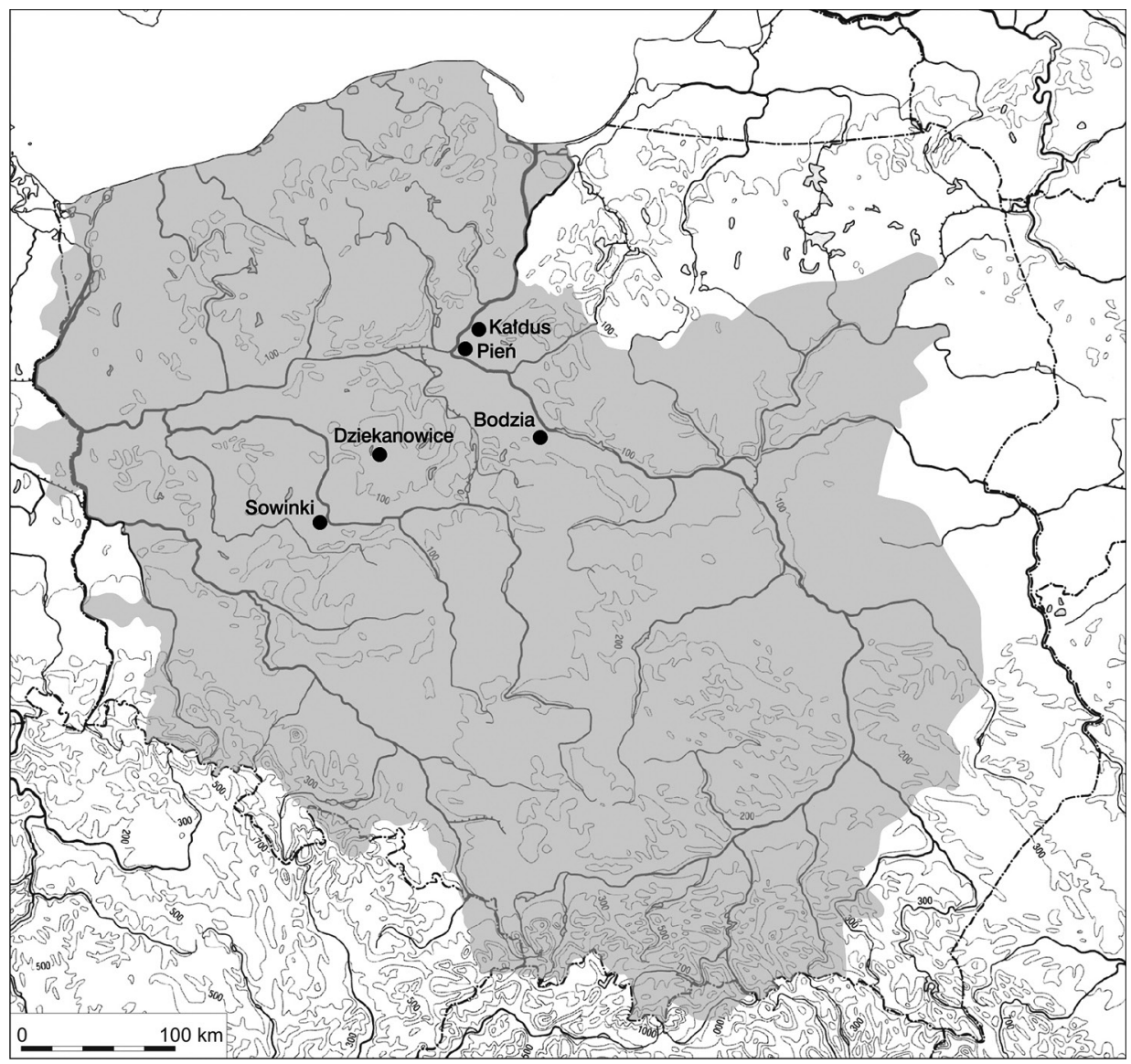

Ryc. 1. Lokalizacja cmentarzysk z grobami komorowymi z okresu wczesnopiastowskiego (X-XI w.) omawianych w tekście; mapa za: M. Bajka, M. Florek, P.N. Kotowicz, Pochówek z czekanem z wczesnośredniowiecznego cmentarzyska na Wzgórzu Miejskim w Sandomierzu, Acta Militaria Mediaevalia 12 (2016), s. 175-198, oprac. J. Żabko-Potopowicz

Groby komorowe znane są z różnych okresów i z różnych obszarów pradziejowej i wczesnośredniowiecznej Europy ${ }^{4}$. Charakteryzowały się występowaniem konstrukcji funeralnej w postaci drewnianej komory składającej się z drewnianych ścian oraz dachu i podłogi. Stanowiły miejsce, w którym składano zmarłego, często

4 Kammergräber im Barbaricum. Zu Einflüssen und Übergangsphänomen von der vorrömischen Eisenzeit bis in die Völkerwanderungszeit, red. A. Abegg-Wigg, N. Lau, NeumünsterHamburg 2010. 
w drewnianej trumnie wraz z, niejednokrotnie bardzo bogatymi, darami grobowymi. Na powierzchni ziemi wznoszono nad nimi najczęściej ziemny kurhan lub tak zwany dom zmarłych w postaci drewnianego budynku. Groby tego typu zarejestrowano także na obszarze ziem polskich wchodzących w skład państwa pierwszych Piastów, gdzie występowały w drugiej połowie X i pierwszej połowie XI w. Do niedawna wczesnośredniowieczne groby komorowe odkrywane na obszarze ziem polskich były przez wielu badaczy interpretowane jako pochówki Skandynawów - wojowników, członków drużyny książęcej pierwszych Piastów oraz kupców i ich rodzin 5 . Obecnie, opierając się na nowszych badaniach i interpretacjach, przyjmuje się, że były one raczej w większości wypadków miejscem pochówku lokalnych, słowiańskich elit państwowych monarchii piastowskiej ${ }^{6}$.

\section{Charakterystyka cmentarzysk z grobami komorowymi}

Bodzia jest położona na Kujawach około 9 km od współczesnego, lewego brzegu Wisły. Cmentarzysko (stanowisko 1) zostało przebadane w latach 2007-2009 w ramach ratowniczych badań wykopaliskowych związanych z budową autostrady A1 przez Kamillę Waszczuk i Sławomira Gronka z Zespołu Ratowniczych Badań Archeologicznych Instytutu Archeologii i Etnologii Polskiej Akademii Nauk w Po-

5 Np. W. Chudziak, Wczesnośredniowieczne groby komorowe z Kałdusa pod Chetmem na Pomorzu Wschodnim, Slavia Antiqua 42 (2001), s. 63-94; tenże, Ślady skandynawskiej obrzędowości w Kałdusie na Pomorzu Wschodnim, [w:] Popiót i kość (Funeralia Lednickie - Spotkanie 4), red. J. Wrzesiński, Sobótka-Wrocław 2002, s. 433-448; tenże, Wikingerzeitliche Spuren des skandinavischen Brauchtums in Kałdus (Ostpommern), Archäologisches Korrespondenzblatt 33 (2003), 1, s. 145-156; B. Stanisławski, Jómswikingowie $z$ Wolina-Jómsborga - studium archeologiczne przenikania kultury skandynawskiej na ziemie polskie, Wrocław 2013.

6 D. Błaszczyk, Między ziemiq a niebem. Groby komorowe na obszarze państwa pierwszych Piastów, Warszawa 2017; L. Gardeła, Wczesnośredniowieczne groby komorowe - lustra czy miraże życia? Rozważania nad praktykami funeralnymi na ziemiach polskich, [w:] Pochówki w grobach komorowych na ziemiach polskich w okresie wczesnego średniowiecza, red. D. Błaszczyk, D. Stępniewska, Warszawa 2016, s. 154-175; A. Janowski, „Jeśli umrze ktoś znaczny z nich, kopia dlań grób podobny do obszernego domu...". Kilka uwag o tzw. grobach komorowych na terenie Europy Środkowej i Wschodniej, [w:] In Silvis, Campis... et Urbe. Średniowieczny obrządek pogrzebowy na pograniczu polsko-ruskim, red. S. Cygan, P.N. Kotowicz, M. Glinianowicz, Rzeszów-Sanok 2011, s. 385-402; tenże, Groby komorowe w Europie Środkowo-Wschodniej. Problemy wybrane, Szczecin 2015; J. Sikora, O interpretacji etnicznej wczesnośredniowiecznych pochówków elitarnych. Skandynawowie w państwie pierwszych Piastów i na Pomorzu?, Slavia Antiqua 44 (2013), s. 61-96. 
znaniu. Odkryto na nim 52 groby zawierające szczątki 55 osób. Nekropolia w Bodzi była użytkowana od drugiej połowy X do końca XI lub pierwszej połowy XII w. Nie udało się dotychczas zidentyfikować żadnej osady ani grodu, które mogły być z pewnością związane z tym cmentarzyskiem. Za grób komorowy może być uznany najstarszy i zapewne założycielski grób mężczyzny D162 datowany na koniec X-początek XI w. ${ }^{7}$

Dziekanowice znajdują się w Wielkopolsce na wschodnim brzegu jeziora Lednica. W okresie wczesnego średniowiecza na połączonej z lądem dwoma drewnianymi mostami wyspie tego jeziora znajdował się gród z podgrodziem. Na grodzie był usytuowany zespół rezydencjonalny, składający się m.in. z kamiennego pałacu połączonego z okrągłą kaplicą, oraz kamienny lub drewniany na kamiennej podmurówce prostokątny kościół grodowy ${ }^{8}$. Obszar wokół jeziora lednickiego był gęsto zasiedlony i zabudowany licznymi osadami otwartymi. Na brzegu jeziora, w pobliżu jednej z przepraw mostowych, znajdowało się rozległe cmentarzysko szkieletowe użytkowane od drugiej połowy X do początku XIII w. Badania na tym cmentarzysku były prowadzone od lat siedemdziesiątych do lat dziewięćdziesiątych XX w., początkowo przez Macieja Henneberga z Uniwersytetu im. Adama Mickiewicza w Poznaniu, a następnie przez Jacka Wrzesińskiego i Annę Wrzesińską z Muzeum Pierwszych Piastów na Lednicy. W wyniku przeprowadzonych na nim prac wykopaliskowych łącznie wyeksplorowano 1585 grobów z 1650 pochówkami. Zarejestrowano na nim sześć grobów komorowych (groby nr I, II, 20, 60, 61, 62) zawierających szczątki jednego dziecka, dwóch kobiet i trzech mężczyzn. Powstały one w drugiej połowie $\mathrm{X}$ i pierwszej połowie XI w. ${ }^{9}$

Również w Wielkopolsce znajdują się położone nad rzeką Wartą Sowinki (stanowisko 23A). Ratownicze badania archeologiczne na cmentarzysku w Sowinkach przeprowadził w latach 1989-1991 Andrzej Krzyszowski z ówczesnej Pracowni Naukowo-Badawczej PKZ w Poznaniu sp. z o.o. Odkopano 150 grobów zawierających szczątki 158 osób, z których dwa były grobami komorowymi zawierającymi szczątki mężczyzn (groby nr 148 i 151). Użytkowanie cmentarzyska w Sowinkach zostało

7 Bodzia. A Late Viking-Age Elite Cemetery in Central Poland, red. A. Buko, Leiden-Boston 2015; Bodzia. Elitarny cmentarz z początków państwa polskiego, red. A. Buko, Warszawa 2016. 8 J. Górecki, Gród na Ostrowie Lednickim na tle wybranych ośrodków grodowych pierwszej monarchii piastowskiej, Lednogóra 2001; Ostrów Lednicki. Rezydencjonalno-stołeczny ośrodek pierwszych Piastów, red. Z. Kurnatowska, A.M. Wyrwa, Warszawa 2016.

9 A. Wrzesińska, J. Wrzesiński, Groby komorowe z Dziekanowic, gm. Łubowo, woj. wielkopolskie, [w:] Pochówki w grobach komorowych, s. 80-89. 
określone na okres od drugiej połowy X do pierwszej połowy XII w., przy czym groby komorowe mogą być datowane na drugą połowę X-pierwszą połowę XI w. ${ }^{10}$ Do tej pory nie udało się zarejestrować osady ani grodziska związanego z funkcjonowaniem cmentarzyska.

Nad Wisłą, na Pomorzu Wschodnim, w części regionu określanego mianem ziemi chełmińskiej, są zlokalizowane dwa kolejne cmentarzyska z wczesnośredniowiecznymi grobami komorowymi w Kałdusie i Pniu. W Kałdusie na tak zwanej górze św. Wawrzyńca istniał kompleks osadniczy składający się z grodu, osady przygrodowej i trzech cmentarzysk, który funkcjonował od X do XII/XIII w. Usytuowany na peryferiach państwa piastowskiego, na pograniczu ziem polskich i pruskich, Kałdus stanowił ważne centrum kulturowe i ekonomiczne oraz pełnił funkcję ośrodka władzy piastowskiej. Był również miejscem sprawowania kultu, pierwotnie pogańskiego, a następnie chrześcijańskiego. W pierwszej połowie XI w., za czasów Bolesława Chrobrego lub Mieszka II, na grodzie w Kałdusie zaczęto wznosić kamienną bazylikę, której budowy jednak nigdy nie ukończono. Wieloletnie badania kompleksu osadniczego prowadziła ekspedycja archeologiczna Uniwersytetu Mikołaja Kopernika w Toruniu pod kierunkiem Wojciecha Chudziaka, Jacka Bojarskiego i Marcina Weinkaufa. W wyniku prac przeprowadzonych na znajdującym się w pobliżu grodu cmentarzysku (stanowisko 4) odkryto 478 grobów zawierających szczątki 482 osób. Z odkrytych grobów siedem, zawierających osiem pochówków, stanowily groby komorowe (groby 13AB, 60, 125, 166, 364, 422, 453), w których pochowano trzech mężczyzn, cztery kobiety, jedno dziecko i jedną osobę o nieokreślonej płci. Groby komorowe mogą być datowane na drugą połowę X i pierwszą połowę XI w. ${ }^{11}$

Z kolei w Pniu usytuowanym około $20 \mathrm{~km}$ na południe od Kałdusa istniał zespół osadniczy złożony z funkcjonującego od połowy X do XII w. grodu, kilku otaczających go osad i cmentarza (stanowisko 9). W latach 2005-2007 i w 2009 r. ratownicze badania archeologiczne na stanowisku prowadzili archeolodzy z Uniwersytetu

10 A. Krzyszowski, Wstępne wyniki badań archeologicznych na wczesnośredniowiecznym cmentarzysku szkieletowym $z$ X/XI-XI wieku w miejscowości Sowinki, gm. Mosina, woj. poznańskie, stanowisko 23A, Wielkopolskie Sprawozdania Archeologiczne 1 (1992), s. 83-102; tenże, Ein reiches Gräberfeld aus dem 10./11. Jh. in Sowinki bei Poznań, Slavia Antiqua 36 (1995), s. 49-72.

11 J. Bojarski, W. Chudziak, T. Kozłowski, L. Reitsema, Wczesnośredniowieczne groby komorowe z ziemi chetmińskiej, [w:] Pochówki w grobach komorowych, s. 102-121; W. Chudziak, Wczesnośredniowieczne groby komorowe, s. 63-94; Wczesnośredniowieczne cmentarzysko szkieletowe w Kałdusie (stanowisko 4), red. W. Chudziak, Toruń 2010. 
Mikołaja Kopernika w Toruniu pod kierunkiem Dariusza Polińskiego z udziałem Andrzeja Janowskiego i Alicji Drozd-Lipińskiej. W ich wyniku odkopano 61 nowożytnych grobów szkieletowych oraz 11 wczesnośredniowiecznych grobów komorowych (groby 15, 32, 37, 38, 39, 40, 49, 57, 69, 71). W grobach tych pochowano siedmioro dzieci, dwie kobiety i jednego mężczyznę oraz konia. Ich chronologia została określona na drugą połowę X i pierwszą połowę XI w. ${ }^{12}$

\section{Dieta w średniowiecznej Polsce}

Na podstawie dotychczasowych badań, opartych przede wszystkim na metodach pośrednich, można stwierdzić, że podstawę pożywienia ludzi zamieszkujących ziemie polskie w okresie wczesnego średniowiecza stanowily rośliny zbożowe, warzywa, owoce i różne produkty zwierzęce. $Z$ roślin zbożowych uprawiano przede wszystkim pszenicę, żyto, jęczmień i proso. Spożywano je w postaci chleba, kaszy, polewek i piwa. Szczególnie w starszych okresach wczesnego średniowiecza (X-XI w. i wcześniej) powszechne było spożywanie prosa, co znajduje swoje potwierdzenie w znaleziskach archeologicznych (ziarna i plewy prosa, odciski na naczyniach i polepie), tekstach pisanych (szczególnie autorów arabskich) oraz izotopowej analizie kości ludzkich ${ }^{13}$. Z warzyw uprawiano m.in. groch, bób, soczewicę, marchew, buraki, brukiew, ogórek, rzodkiew, cebulę i kapustę, a z owoców znano wiśnie, jabłka, śliwki, gruszki i brzoskwinie ${ }^{14}$.

12 J. Bojarski, W. Chudziak, T. Kozłowski, L. Reitsema, Wczesnośredniowieczne groby komorowe, s. 102-121; A. Drozd, A. Janowski, D. Poliński, Wczesnośredniowieczne groby komorowe na cmentarzysku w Pniu koło Bydgoszczy (Badania 2005-2007), [w:] XVI sesja pomorzoznawcza, t. 1: Od epoki kamienia do okresu wczesnośredniowiecznego, red. A. Janowski, K. Kowalski, S. Słowiński, Szczecin 2009, s. 351-366; A. Drozd, A. Janowski, D. Poliński, Badania ratownicze przeprowadzone w 2009 roku na średniowieczno-nowożytnym cmentarzysku w Pniu, gm. Dabrowa Chetmińska, woj. kujawsko-pomorskie (stanowisko 9), [w:] XVII sesja pomorzoznawcza, t. 1: Od epoki kamienia do wczesnego średniowiecza, red. M. Fudziński, H. Paner, Gdańsk 2011, s. 513-522.

13 L.J. Reitsema, D.E. Crews, M. Polcyn, Preliminary evidence for medieval Polish diet from carbon and nitrogen stable isotopes, Journal of Archaeological Science 37 (2010), s. 1413-1423. 14 M. Dembińska, Konsumpcja żywności w Polsce wczesnośredniowiecznej, Wrocław-Warszawa-Kraków 1963; M. Lityńska-Zając, D. Nalepka, Średniowieczny świat roślin i pożywienie w świetle źródet paleobotanicznych, [w: ] Źródła historyczne wydobywane z ziemi, red. S. Suchodolski, Wrocław 2008, s. 57-77. 
W różnych ilościach spożywano mięso i produkty zwierzęce, takie jak mleko i jajka. Najpopularniejsze były świnie, których szczątki dominują w kontekstach archeologicznych, ponadto hodowano krowy, owce, kozy oraz kury, kaczki i gęsi. Oprócz zwierząt udomowionych na stanowiskach archeologicznych z omawianego okresu znajdowane są również szczątki zwierząt dzikich (zając, sarna, jeleń, łoś, tur, niedźwiedź) oraz ryb ${ }^{15}$. Ze źródeł historycznych i archeologicznych wynika, że jedzono takie ryby jak śledź, ryby dorszowate, łosoś, pstrąg, troć, sieja, okoń, szczupak, sum, karp, leszcz, płoć, lin, węgorz i jesiotr oraz raki. Niektóre gatunki były bardziej dostępne dla warstw wyższych niż dla niższych, np. jesiotr i sum. Udział w diecie ryb potwierdzają również wyniki badań izotopowych ${ }^{16}$. Z napojów pito wodę, piwo i miód pitny, a wśród elit zapewne również wino. Piwo warzono z jęczmienia, pszenicy i prosa.

W średniowieczu dieta ulegała różnym zmianom, istotnie różniła się też między wyższymi i niższymi warstwami społeczeństwa. Bez wątpienia za jeden z najbardziej wartościowych i prestiżowych rodzajów pożywienia w tym czasie było uznawane mięso. Zwykli ludzie jedli przede wszystkim mięso zwierząt domowych, natomiast ludzie z elit konsumowali częściej dziczyznę i ryby. Ważnym czynnikiem, który wpływał na dietę średniowiecznych mieszkańców ziem polskich, były wprowadzane od drugiej połowy $\mathrm{X}$ w. w wyniku chrystianizacji posty, w czasie których nie jedzono produktów zwierzęcych takich jak mięso, jajka, mleko i sery.

\section{Zastosowanie metod izotopowych w badaniach diety}

Metody izotopowe stosowane $\mathrm{w}$ archeologii wykorzystują zależności, jakie występują pomiędzy składem izotopowym pożywienia a składem niektórych tkanek. Metoda badawcza polega na określeniu sygnatur izotopowych w tkankach badanych organizmów, a następnie porównanie uzyskanych danych z sygnaturami izotopowymi charakterystycznymi dla różnych typów pożywienia i ekosystemów ${ }^{17}$ (ryc. 2).

15 U. Iwaszczuk, Animal husbandry on the Polish territory in the Early Middle Ages, Quaternary International 346 (2014), s. 69-101 (doi.org/10.1016/j.quaint.2014.03.012); A. Gręzak, B. Kurach, Konsumpcja mięsa $w$ średniowieczu oraz $w$ czasach nowożytnych na terenie obecnych ziem Polski w świetle badań archeologicznych, Archeologia Polski 41 (1996), s. 139-167. 16 D. Makowiecki, Historia ryb i rybołówstwa $w$ holocenie na Niżu Polskim $w$ świetle badań archeoichtiologicznych, Poznań 2003; tenże, Some remarks on medieval fishing in Poland, [w: ] Animals and man in the past, ed. by H. Buitenhuis, W. Prummel, Groningen 2001, s. 236-241; L.J. Reitsema, D.E. Crews, M. Polcyn, Preliminary evidence, s. 1419.

17 T. Brown, K. Brown, Biomolecular archaeology. An introduction, Chichester 2011; S. Mays, 


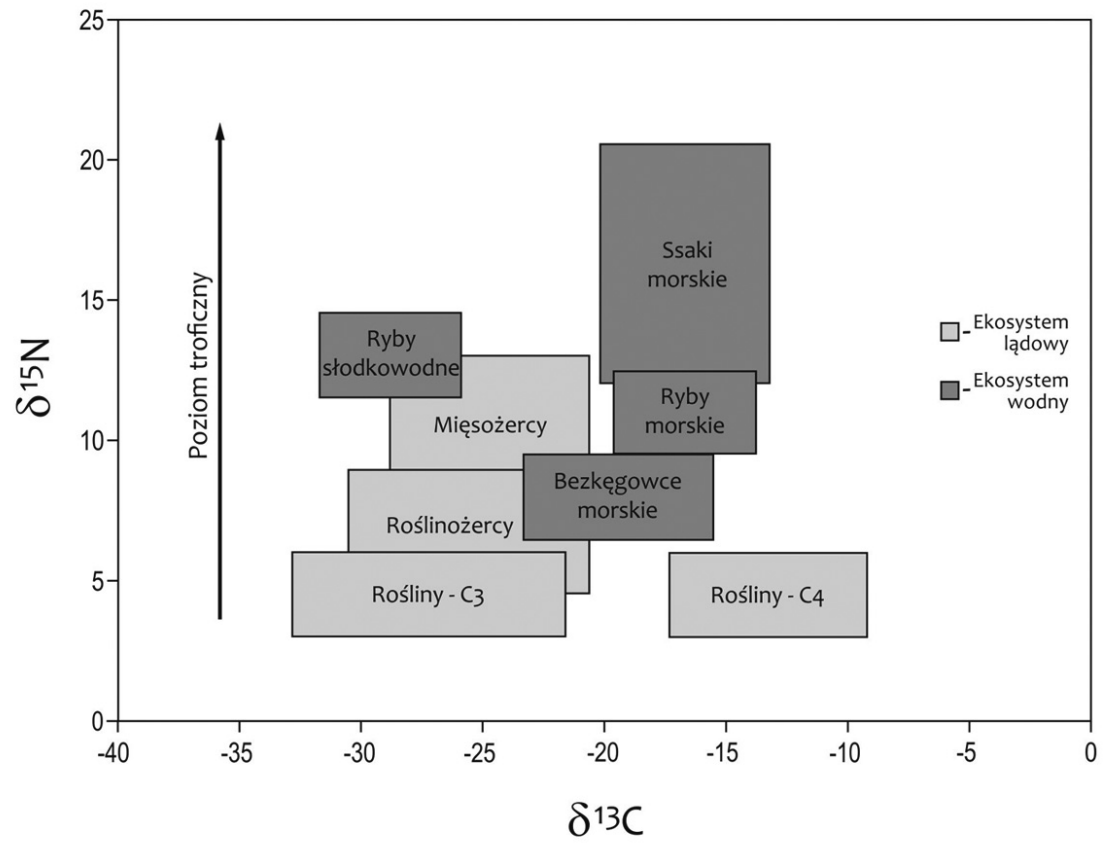

Ryc. 2. Wartości węgla $\delta^{13} \mathrm{C}$ i azotu $\delta^{15} \mathrm{~N}$ w różnych rodzajach pożywienia; za K. Szostek, B. Stepańczak, Zastosowanie analizy stabilnych izotopów w antropologii - wstępne wyniki badań, [w:] Metody. Źródła. Dokumentacja (Funeralia Lednickie. Spotkanie 11), red. W. Dzieduszycki, J. Wrzesiński, Poznań 2009, s. 125-140, oprac. B. Bednarczyk

Do rekonstrukcji diety wykorzystuje się pomiary izotopów węgla $\left(\delta^{13} \mathrm{C}\right)$ i azotu $\left(\delta^{15} \mathrm{~N}\right)$ w kolagenie kości. Kolagen jest stosunkowo trwały, zachowuje się przez tysiące lat i jest odporny na pośmiertne zmiany stosunków izotopowych. Najlepiej do wyizolowania kolagenu nadaje się istota zbita kości i zębina. Wynika to z tego, że zawierają one duże ilości tego białka i są najmniej narażone na chemiczne i fizyczne zanieczyszczenia pośmiertne. Zębina dostarcza informacji o diecie w okresie dzieciństwa, a istota zbita kości informuje o niej w okresie dorosłości. Próbki istoty zbitej do badań izotopowych pobiera się z trzonu kości długich (głównie z kości udowej, piszczelowej, ramieniowej i promieniowej) lub żeber. Skład izotopowy kości jest uwarunkowany z jednej strony rodzajem spożywanych pokarmów, a z drugiej strony

The archaeology of human bones; K. Szostek, B. Stepańczak, Zastosowanie analizy stabilnych izotopów w antropologii - wstępne wyniki badań, [w: ] Metody. Źródła. Dokumentacja (Funeralia Lednickie. Spotkanie 11), red. W. Dzieduszycki, J. Wrzesiński, Poznań 2009, s. 125-140. 
okresem, w którym zachodzi tzw. remodeling tkanki kostnej. Tym terminem określa się okres, w jakim dochodzi do całkowitej wymiany ponad połowy składników budujących kości. Zatem skład izotopowy kości długich odzwierciedla, w przypadku dorosłych, ostatnie 7-10 lat, a w wypadku dzieci ostatni rok życia. W odniesieniu do żeber są to ostatnie 3-4 lata. Węgiel budujący kolagen kostny pochodzi przede wszystkim ze spożywanych białek, a w przypadku diety ubogiej w proteiny również z węglowodanów i tłuszczów. Azot natomiast dostarczany jest prawie wyłącznie $\mathrm{z}$ białek. Jednoczesna analiza składu izotopów węgla i azotu pozwala na ustalenie głównych źródeł spożywanych protein ${ }^{18}$.

W celu określenia stosunków izotopowych węgla i azotu kolagen musi zostać wyekstrahowany ze szczątków kostnych i oczyszczony, a uzyskany w ten sposób materiał należy poddać analizie w spektrometrze masowym. Uzyskane wyniki przedstawiane są jako parametr delta $(\delta)$, wyrażony w promilach (\%), który obrazuje odchylenie stosunku izotopowego próbki w stosunku do składu izotopowego wzorca. Dla izotopów węgla wzorcem jest skład izotopowy węglanu, tzw. VPDB (ang. Vienna Pee Dee Belemnite), a dla azotu AIR (ang. Ambient Inhalable Reservoir), czyli azot zawarty $\mathrm{w}$ atmosferze. Ponieważ wartość stosunku izotopowego węgla w materiale biologicznym jest mniejsza niż w standardzie, więc parametr $\delta^{13} \mathrm{C}$ przyjmuje wartości ujemne. Natomiast stosunek izotopowy azotu w tkankach organicznych jest wyższy niż w standardzie, stąd parametr $\delta^{15} \mathrm{~N}$ jest dodatni. Pomimo swojej trwałości kolagen, jak każda substancja organiczna, ulega zanieczyszczeniu i degradacji, przechodząc w białka niekolagenowe. $\mathrm{W}$ celu określenia, czy kolagen nadaje się do badań, sprawdza się stosunek węgla do azotu $(\mathrm{C} / \mathrm{N})$ oraz zawartość węgla $(\% \mathrm{C})$ i azotu $(\% \mathrm{~N})$ w kolagenie. Aby materiał kostny pochodzący z wykopalisk nadawał się do badań, wskaźnik $\mathrm{C} / \mathrm{N}$ powinien się mieścić w przedziale 2,9-3,6, natomiast udział procentowy węgla w kolagenie powinien wynosić powyżej $10 \%$, a azotu ponad $4 \%{ }^{19}$.

18 Ł. Pospieszny, Z. Bełka, Dieta i mobilność u schyłku starożytności. Szczątki ludzkie $z$ cmentarzyska $w$ Karczynie/Witowach stan. 21/22 w świetle badań izotopowych, [w:] Karczyn/Witowy stan. 21/22. Birytualne cmentarzyska kultury przeworskiej z Kujaw, red. A. Romańska, J. Bednarczyk, Poznań-Inowrocław 2015, s. 171-187; K. Szostek, B. Stepańczak, Zastosowanie analizy, s. 125-140.

19 S.H. Ambrose, Preparation and characterization of bone and tooth collagen for isotopic analysis, Journal of Archaeological Science 17 (1990), s. 431-451; M.J. DeNiro, Postmortem preservation and alteration of in vivo bone collagen isotope ratios in relation to palaeodietary reconstruction, Nature 317 (1985), s. 806-809, doi.org/10.1038/317806a0; G.J. van Klinken, Bone Collagen Quality Indicators for Palaeodietary and Radiocarbon Measurements, Journal of Archaeological Science 26 (1999), s. 687-695, doi.org/10.1006/jasc.1998.0385. 
Węgiel występuje w środowisku w postaci dwóch trwałych izotopów ${ }^{12} \mathrm{C}(98,9 \%)$ $\mathrm{i}^{13} \mathrm{C}(1,1 \%)$. Stosunek stałych izotopów węgla ${ }^{12} \mathrm{C} /{ }^{13} \mathrm{C}$ pozwala określić, z jakiego ekosystemu pochodziło pożywienie. Różnica w wartości $\delta^{13} \mathrm{C}$ pomiędzy organizmami zasiedlającymi ekosystemy lądowe i wodne umożliwia stwierdzenie, czy dieta składała się z organizmów lądowych, wodnych, czy obydwu źródeł pokarmu. Z kolei różnica w proporcji stabilnych izotopów węgla w tkankach roślin, związana z typem przeprowadzanej fotosyntezy, pozwala określić rodzaj spożywanego pokarmu roślinnego. Wyróżnia się trzy typy fotosyntezy: $\mathrm{C}_{3}, \mathrm{C}_{4}$ i CAM. Rośliny CAM są spotykane tylko w klimacie gorącym (np. kaktusy, ananas). Rośliny $\mathrm{C}_{3}$ przyswajają cząstki trójwęglowe i wbudowują w tkanki mniej węgla ${ }^{13} \mathrm{C}$. Rosną głównie w klimacie umiarkowanym i są to zboża (np. pszenica, żyto, jęczmień, ryż), trawy, warzywa, większość owoców. Rośliny $\mathrm{C}_{4}$ przyswajają cząsteczki czterowęglowe i wbudowują $\mathrm{w}$ tkanki więcej węgla ${ }^{13} \mathrm{C}$. Występują przede wszystkim w klimacie tropikalnym i subtropikalnym i są to takie rośliny jak proso, kukurydza, sorgo, trzcina cukrowa. W związku z tym wartość $\delta^{13} \mathrm{C}$ dla roślin typu $\mathrm{C}_{3}$ wynosi od - 35\%o do - $20 \%$, a dla roślin $\mathrm{C}_{4}$ od - $14 \%$ o do $-9 \% \mathrm{o}^{20}$.

Azot posiada dwa trwałe izotopy ${ }^{14} \mathrm{~N}(99,6 \%) \mathrm{i}^{15} \mathrm{~N}(0,4 \%)$. W związku z tym, że jest podstawowym składnikiem budowy białka w organizmach żywych, badanie stosunku jego izotopów pozwala określić rodzaj spożywanego pokarmu (dostęp do produktów zwierzęcych) i poziom troficzny organizmu (roślinożerca, mięsożerca, wszystkożerca). Wraz ze wzrostem pozycji organizmu w sieci troficznej wartość $\delta^{15} \mathrm{~N}$ rośnie o 3-4\%o, w związku z czym mięsożercy posiadają wyższą wartość $\delta^{15} \mathrm{~N}$ niż roślinożercy ${ }^{21}$.

\section{Materiał i metody}

Ekstrakcja kolagenu i pomiary $\delta^{13} \mathrm{C}$ i $\delta^{15} \mathrm{~N}$ szczątków ludzkich z grobów komorowych w Bodzi, Dziekanowicach, Pniu i Sowinkach zostały wykonane w Stable Isotope Facility, University of Bradford. Pomiary wykonano dla szczątków z grobu D162 w Bodzi, II, 20, 61, 62 z Dziekanowic, 32, 37, 38, 39, 40, 49, 57, 69, 71 w Pniu i 148, 151 w Sowinkach. Dodatkowo wykorzystano wyniki badań grobów komorowych $13 \mathrm{AB}$ i 60 z Kałdusa wykonane przez Laurie Reitsema w Stable Biogeochemistry

20 S. Mays, The archaeology of human bones, s. 275-268; K. Szostek, B. Stepańczak, Zastosowanie analizy, s. 129-130.

21 Tamże. 
Laboratory, Ohio State University ${ }^{22}$. Próbki do badań pobrano z żeber. Ogółem analizę wykonano dla 19 osób pochowanych w grobach komorowych, w tym ośmiu mężczyzn, czterech kobiet i siedmiorga dzieci. Osoby te zmarly w kategoriach wieku: infans I (6), infans II (1), juvenis (3), adultus (4), maturus (4) i adultus/maturus (1) (tab. 3, ryc. 3). Trzeba przy tym zaznaczyć, że dwaj mężczyźni z Sowinek oznaczani jako juvenis mogli być w istocie starsi. Ich wiek mógł zostać błędnie określony (niedoszacowany) ze względu na bardzo słaby stan zachowania kości.

Analizowane izotopy węgla i azotu pochodziły z kolagenu kostnego, który został wyizolowany z fragmentów istoty zbitej z zastosowaniem zmodyfikowanej procedury R. Longina ${ }^{23}$. Próbki zostały oczyszczone przez usunięcie zewnętrznych powierzchni za pomocą wiertła, a następnie poddane demineralizacji w roztworze kwasu solnego $(0,5 \mathrm{M}) \mathrm{w}$ temperaturze $4^{\circ} \mathrm{C}$. Przed przystąpieniem do następnego kroku kwas z probówek został wypłukany za pomocą wody dejonizowanej. Próbki umieszczono z kolei w szczelnie zamkniętych mikroprobówkach, ogrzano w rozcieńczonym roztworze kwasu solnego o $\mathrm{pH} 3 \mathrm{w}$ temperaturze $70^{\circ} \mathrm{C}$ przez 48 godzin, umożliwiając denaturację włókien kolagenu. Tak przygotowane próbki zostały zamrożone i poddane liofilizacji. Pomiary trwałych izotopów węgla i azotu zostały wykonane w Stable Light Isotope Laboratory, University of Bradford za pomocą Thermo Flash EA 1112 połączonego Conflo III ze spektrometrem mas Delta Plus XL. Pomiar dla każdej próbki wykonano dwukrotnie i porównano ze standardami laboratoryjnymi (żelatyna ryb oraz wątroba bydlęca) i międzynarodowymi (IAEA 600, CH6, CH7, N1 i N2). Wartości składu izotopowego azotu i węgla wyrażono w postaci notacji delta $\delta\left(\delta^{15} \mathrm{~N}, \delta^{13} \mathrm{C}\right)$ i podano w promilach (\%o) w odniesieniu do międzynarodowych wzorców Vienna-PDB dla $\delta^{13} \mathrm{C}$ i AIR dla $\delta^{15} \mathrm{~N}$. Błąd analityczny przyjęto na poziomie $\pm 0,2 \%$ ( 1 o.s.) lub wyższym.

Jako materiał porównawczy z ziem polskich wykorzystano wyniki badań izotopów węgla i azotu otrzymane dla populacji z okresu wpływów rzymskich z Rogowa, stan. 2, kultura wielbarska, II w. ${ }^{24}$ i Karczyna/Witowów, stan. 21/22, kultura przeworska ${ }^{25}$;

22 J. Bojarski, W. Chudziak, T. Kozłowski, L. Reitsema, Wczesnośredniowieczne groby komorowe, s. 102-121; L.J. Reitsema, T. Kozłowski, D.E. Crews, M.A. Katzenberg, W. Chudziak, Resiliance, s. 38-52.

23 R. Longin, New method of collagen extraction for radiocarbon dating, Nature 230 (1971), s. 241-242.

24 L.J. Reitsema, T. Kozłowski, Diet and society in Poland before the state: stable isotope evidence from Wielbark population ( $2^{\text {nd }}$ c. AD), Anthropological Review 76 (2013), 1, s. 1-22.

Ł. Pospieszny, Z. Bełka, Dieta i mobilność, s. 171-187. 
wczesnego średniowiecza z Giecza, stan. 4, XI-XII w. ${ }^{26}$, Kałdusa, stan. 4, X-XI w., Kałdusa, stan. 1, XII-XIII w. i Gruczna, stan. 1, XII w. oraz późnego średniowiecza z Gruczna, stan. 2, XIII-XIV w. ${ }^{27}$ Dodatkowo wykorzystano wyniki badań izotopów węgla i azotu uzyskane dla cmentarzyska z wczesnej epoki żelaza w miejscowości Magdalenska Gora $\mathrm{w}$ Słoweniii ${ }^{28}$, osady z okresu wikińskiego w Birce w Szwecji, IX-X w..$^{29}$, elit państwa polsko-litewskiego z Polski (XVII-XIX w.; Przemyśl, Warszawa, Końskowola, Wschowa) i z Litwy (XV-XVIII w.; Wilno) ${ }^{30}$ (tab. 1, ryc. 3).

Tabela 1. Wyniki badań izotopów węgla i azotu wybranych populacji ludzkich z cmentarzysk

\begin{tabular}{|l|c|c|c|c|c|}
\hline \multicolumn{1}{|c|}{ Stanowisko } & Próba & $\boldsymbol{\delta}^{15} \mathbf{N} \%$ o & Średnia \%o & $\boldsymbol{\delta}^{13} \mathbf{C} \%$ o & Średnia \%o \\
\hline Rogowo, stan. 2 & 30 & $8,6-10,9$ & $9,7 \pm 0,5$ & $-16,4--19,5$ & $-17,9 \pm 0,7$ \\
\hline Karczyn/Witowy, stan. 21/22 & 30 & $8,1-10,9$ & $9,18 \pm 0,9$ & $-12,1--20,2$ & $-18,3 \pm 2,4$ \\
\hline Giecz, stan. 4 & 24 & $7,9-10,0$ & $9,2 \pm 0,6$ & $-18,0--19,4$ & $-18,9 \pm 0,4$ \\
\hline Kałdus, stan. 4 & 33 & $8,7-11,9$ & $10,1 \pm 0,7$ & $-20,3--16,3$ & $-18,6 \pm 0,9$ \\
\hline Kałdus, stan. 1 & 30 & $8,7-11,6$ & $10,2 \pm 0,7$ & $-20,5--18,7$ & $-19,5 \pm 0,4$ \\
\hline Gruczno, stan. 1 & 34 & $8,1-11,2$ & $9,4 \pm 0,7$ & $-20,0--18,9$ & $-19,8 \pm 0,4$ \\
\hline Gruczno, stan. 2 & 32 & $7,6-10,7$ & $9,3 \pm 0,7$ & $-20,8--19,5$ & $-20,1 \pm 0,4$ \\
\hline Birka & 22 & $11,5-16,5$ & $13,6 \pm 1,1$ & $-21,1--19,0$ & $-20,0 \pm 1,1$ \\
\hline Magdalenska Gora & 19 & $5,4-10,6$ & $9,4 \pm 1,1$ & $-20,0--13,00$ & $-14,7 \pm 1,6$ \\
\hline Elity Polska & 14 & $12,3-14,2$ & $13,6 \pm 0,6$ & $-19,8--18,9$ & $-19,5 \pm 0,3$ \\
\hline Elity Litwa & 35 & $9,5-11,5$ & $11,7 \pm 0,7$ & $-20,4--19,2$ & $-19,9 \pm 0,2$ \\
\hline
\end{tabular}

Dieta osób z cmentarzyska w Rogowie była oparta na konsumpcji roślin $\mathrm{C}_{3}$ $\mathrm{z}$ istotnym udziałem prosa oraz być może pewnej ilości ryb morskich. Dieta osób

26 L.J. Reitsema, D.E. Crews, M. Polcyn, Preliminary evidence, s. 1413-1423.
27 L.J. Reitsema, T. Kozłowski, Wstępne sprawozdanie z analiz izotopowych szczątków ludzkich i zwierzęcych, [w:] Wczesnośredniowieczne cmentarzysko szkieletowe w Kałdusie (stanowisko 4), red. W. Chudziak, Toruń 2010, s. 135-138; L.J. Reitsema, T. Kozłowski, D.E. Crews, M.A. Katzenberg, W. Chudziak, Resiliance, s. 38-52.

28 M.L. Murray, M.J. Schoeninger, Diet, status and complex social structure in Iron Age Central Europe: Some contributions of bone chemistry, [w:] Tribe and polity in late prehistoric Europe. Demography, production, and exchange in the evolution of complex social systems, ed. by D.B. Gibson, M.N. Geselowitz, New York 1988, s. 155-176.

29 A. Linderholm, Ch.H. Jonson, O. Svensk, K. Lidén, Diet and status in Birka: stable isotopes and grave goods compared, Antiquity 82 (2008), s. 446-461.

30 L.J. Reitsema, T. Kozłowski, R. Jankauskas, A. Drążkowska, M. Krajewska, Dieta przedstawicieli elit społecznych Rzeczypospolitej na podstawie analizy stabilnych izotopów węgla $i$ azotu w szczątkach szkieletowych, [w:] Kultura funeralna elit Rzeczypospolitej od XVI do XVIII wieku, red. A. Drążkowska, Toruń 2015 , s. 230-246. 
pochowanych w Karczynie miała charakter mieszany i składała się z roślin cyklu $\mathrm{C}_{3}$ $\mathrm{z}$ udziałem roślin $\mathrm{C}_{4}$ oraz produktów zwierząt lądowych, być może z pewnym udziałem ryb słodkowodnych. Dieta osób pochowanych na cmentarzyskach ze starszych faz wczesnego średniowiecza w Kałdusie, stan. 4 i Gieczu składała się z roślin cyklu $\mathrm{C}_{3} \mathrm{z}$ udziałem roślin $\mathrm{C}_{4} \mathrm{i}$ produktów zwierzęcych z pewnym udziałem ryb dwuśrodowiskowych lub słonowodnych w przypadku Kałdusa stan. 4 i słodkowodnych w odniesieniu do Giecza. Dieta osób pochowanych na cmentarzyskach z młodszych faz wczesnego średniowiecza i z późnego średniowiecza XII-XIV w. odkrytych w Kałdusie stan. 1 oraz Grucznie stan. 1 i 2 była w przeważającej mierze oparta na roślinach cyklu $\mathrm{C}_{3}$ (zboża, warzywa i owoce), z większym lub mniejszym udziałem produktów zwierzęcych (mięso, mleko i jajka). Osoby pochowane na cmentarzysku w Magdalenskiej Gorze spożywały przede wszystkim rośliny cyklu $\mathrm{C}_{4}$ (proso) $\mathrm{z}$ udziałem produktów zwierzęcych. Mieszkańcy Birki jedli przede wszystkim rośliny cyklu $\mathrm{C}_{3}$ oraz ryby słodkowodne. Dieta elit polskich i litewskich była oparta na roślinach $\mathrm{C}_{3}$ i produktach zwierzęcych oraz rybach słodkowodnych (ryc. 3).

Jako tło dla diety ludzi wykorzystano również wyniki badań izotopów węgla i azotu szczątków zwierzęcych reprezentujących: dzikie zwierzęta roślinożerne (zając, łoś, tur, żubr, jeleń), udomowione roślinożerne (koń, bydło, owca/koza), udomowione wszystkożerne (świnia, kura), udomowione mięsożerne (pies) oraz ryby słodkowodne (sum, karp, lin, szczupak, sandacz i nieokreślonego gatunku) i dwuśrodowiskowe (jesiotr) (tab. 2). Pochodziły one ze średniowiecznych stanowisk w Bodzi, Dziekanowicach, Gieczu, Kałdusie, Mosinie i Pniu ${ }^{31}$. Dane dla populacji porównawczych i zwierząt zostały podane z zaznaczeniem średniej, odchylenia standardowego ( \pm 1 o.s.) i zakresu wartości (tab. 1,2).

Tabela 2. Wartości trwałych izotopów węgla i azotu zwierząt stanowiących tło dla badanych populacji ludzkich

\begin{tabular}{|l|c|c|c|c|c|}
\hline \multicolumn{1}{|c|}{ Stanowisko } & Próba & $\boldsymbol{\delta}^{15} \mathbf{N} \% \mathbf{o}$ & Średnia \%o & $\boldsymbol{\delta}^{13} \mathbf{C} \% \mathbf{o}$ & Średnia \%o \\
\hline dzikie roślinożerne & 9 & $3,8-6,2$ & $4,8 \pm 0,9$ & $-23,2--21,5$ & $-22,2 \pm 0,6$ \\
\hline domowe roślinożerne & 33 & $4,6-8,9$ & $6,4 \pm 1,0$ & $-26,1--20,7$ & $-21,9 \pm 1,0$ \\
\hline
\end{tabular}

31 D. Błaszczyk, Pochodzenie i dieta mężczyzny pochowanego $w$ grobie D162 z cmentarzyska $w$ Bodzi w świetle badań izotopowych, Światowit, Fascykuł A/B 13-14/54-55 (2018), s. 133-157; L.J. Reitsema, M. Krajewska, T. Kozłowski, Comparative Perspectives on Subadult Dietary Variation in North-Central Poland, 10-19th c. AD, American Journal of Physical Anthropology 156 (2015), s. 264-265; L.J. Reitsema, D.E. Crews, M. Polcyn, Preliminary evidence, s. 1417, tab. 1; L.J. Reitsema, T. Kozłowski, D.E. Crews, M.A. Katzenberg, W. Chudziak, Resiliance, s. 46, tab. 3. 


\begin{tabular}{|l|r|c|c|c|c|}
\hline świnia & 14 & $4,7-9,7$ & $7,2 \pm 1,4$ & $-23,4--17,6$ & $-21,3 \pm 1,4$ \\
\hline kura & 5 & $7,5-10,4$ & $9,2 \pm 1,1$ & $-22,0--18,2$ & $-20,1 \pm 1,5$ \\
\hline pies & 4 & $9,6-10,5$ & $10,1 \pm 0,4$ & $-20,6--19,7$ & $-20,6 \pm 0,9$ \\
\hline ryby słodkowodne & 17 & $5,2-12,3$ & $9,4 \pm 2,3$ & $-28,2--20,2$ & $-24,6 \pm 2,0$ \\
\hline jesiotr & 3 & $9,9-11,3$ & $10,6 \pm 0,7$ & $-17,1--15,6$ & $-16,5 \pm 0,8$ \\
\hline
\end{tabular}

Dzikie roślinożerne: zając, łoś, tur, żubr, jeleń; domowe roślinożerne: koń, bydło, owca/koza; ryby słodkowodne: szczupak, leszcz, sum, sandacz, lin.

Średnia wartość $\delta^{15} \mathrm{~N}$ dla dzikich zwierząt roślinożernych wynosiła 4,8 $\pm 0,9 \%$, a wartość $\delta^{13} \mathrm{C}-22,2 \pm 0,6 \%$, z kolei w przypadku udomowionych zwierząt roślinożernych wartość $\delta^{15} \mathrm{~N}$ wynosiła $6,4 \pm 1,0 \%$, a $\delta^{13} \mathrm{C}-21,9 \pm 1,0 \%$ (tab. 2, ryc. 4). Wartość ${ }^{15} \mathrm{~N}$ była wyższa o 1,6\% w wypadku tych ostatnich, co wynika z tego, że mogły być one karmione odpadkami pochodzącymi z pożywienia spożywanego przez ludzi i/lub być wypasane na nawożonych polach. W przypadku udomowionych zwierząt wszystkożernych i mięsożernych średnie wartości $\delta^{15} \mathrm{~N}$ wynosily - świnia 7,2 $\pm 1,4 \%$,

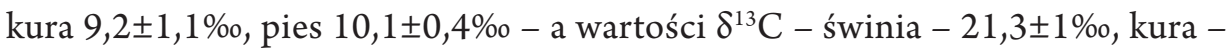
$20,1 \pm 1,5 \%$, pies $-20,6 \pm 0,9 \%$ (tab. 2). Wysokie wartości $\delta^{15} \mathrm{~N}$ wśród tych zwierząt wynikają zapewne ze spożywania odpadków z jedzenia zjadanego przez ludzi, zawierających proteiny zwierzęce oraz innych źródeł protein pochodzenia naturalnego i osiągają najwyższe wartości w wypadku kur i psów. Są one zbliżone do wartości azotu występujących u ludzi. Ryby w większości mają stosunkowo wysokie średnie wartości $\delta^{15} \mathrm{~N} 9,4 \pm 2,3 \%$ i niskie $\delta^{13} \mathrm{C} 24,6 \pm 2,0 \%$ o typowe dla ryb słodkowodnych, natomiast jesiotry charakteryzują wyższe wartości $\delta^{13} \mathrm{C}-16,5 \pm 0,8 \%$, typowe dla tzw. ryb dwuśrodowiskowych (tab. 2).

Istnienie istotnych różnic $\mathrm{w}$ diecie między należącymi do elit społecznych osobami pochowanymi w grobach komorowych i nienależącymi do elit osobami złożonymi w zwykłych grobach jamowych oraz między mężczyznami i kobietami pochowanymi w grobach komorowych sprawdzono za pomocą testów statystycznych. $\mathrm{W}$ wypadku istnienia rozkładu normalnego danych posłużono się testem parametrycznym t-Welcha, natomiast w przypadku braku rozkładu normalnego użyto testu nieparametrycznego Manna-Whitneya. Rozkład danych przetestowano posługując się testem Shapiro-Wilka.

\section{Wyniki i dyskusja}

Wyniki badań trwałych izotopów węgla i azotu w kolagenie kości osób pochowanych w grobach komorowych na obszarze państwa wczesnopiastowskiego przedsta- 
wia tabela 3. Wartość proporcji węgla do azotu $(\mathrm{C} / \mathrm{N})$ w badanych próbkach mieściła się w zakresie 3,2-3,4, zawartość azotu w próbkach wynosiła 8,8-19,3\%, a węgla 25,9-52,5\%, co wskazuje na dobrze zachowany kolagen, który nie uległ zmianom diagenetycznym (tab. 3).

Średnia wartość $\delta^{13} \mathrm{C}$ dla wszystkich osób dorosłych pochowanych w grobach komorowych wynosiła $-17,7 \pm 1,1 \%$, a średnia wartość $\delta^{15} \mathrm{~N} 10,5 \pm 0 \%$. W przypadku mężczyzn było to odpowiednio $\delta^{13} \mathrm{C}-18,0 \pm 1,2 \%$ i $\delta^{15} \mathrm{~N} 10,8 \pm 0,7 \%$, w odniesieniu do kobiet $\delta^{13} \mathrm{C}-17,7 \pm 0,6 \%$ i $\delta^{15} \mathrm{~N} 9,9 \pm 0,3 \%$. Dzieci miały średnią wartość na poziomie $\delta^{13} \mathrm{C}-17,9 \pm 0,4 \%$ i $\delta^{15} \mathrm{~N} 10,0 \pm 1,1 \%$ (tab. 3,4 ).

Tabela 3. Wartości trwałych izotopów azotu i węgla w kolagenie kości osób pochowanych w grobach komorowych z obszaru państwa wczesnopiastowskiego

\begin{tabular}{|c|c|c|c|c|c|c|c|}
\hline Stanowisko & Płeć i wiek & $\delta^{13} \mathrm{~N}$ & $\delta^{13} \mathrm{C}$ & $\% \mathbf{N}$ & $\% \mathrm{C}$ & $\mathrm{C} / \mathrm{N}$ & Laboratorium \\
\hline \multicolumn{8}{|l|}{ Bodzia, stan. 1} \\
\hline grób D162 & mężczyzna maturus & 9,4 & $-18,9$ & 15,9 & 43,7 & 3,2 & Bradford \\
\hline \multicolumn{8}{|c|}{ Dziekanowice, stan. 22} \\
\hline grób 20 & mężczyzna maturus & 10,3 & $-19,0$ & 15,1 & 42,0 & 3,2 & Bradford \\
\hline grób 61 & mężczyzna juvenis & 11,5 & $-18,2$ & 19,3 & 52,5 & 3,2 & Bradford \\
\hline grób 62 & kobieta adultus & 10,1 & $-17,6$ & 19,3 & 52,5 & 3,2 & Bradford \\
\hline grób II & mężczyzna maturus & 11,6 & $-17,4$ & 8,8 & 25,9 & 3,4 & Bradford \\
\hline \multicolumn{8}{|l|}{ Kałdus, stan. 4} \\
\hline grób 13A & mężczyzna adultus & 11,3 & $-17,7$ & 12,2 & 34,8 & 3,3 & Ohio \\
\hline grób 13B & kobieta adultus & 9,5 & $-16,4$ & 10,0 & 27,7 & 3,3 & Ohio \\
\hline grób 60 & mężczyzna adultus/maturus & 11,1 & $-20,1$ & 14,4 & 40,0 & 3,2 & Ohio \\
\hline \multicolumn{8}{|l|}{ Pień, stan. 9} \\
\hline grób 32 & kobieta maturus & 10,1 & $-17,2$ & 15,5 & 42,7 & 3,2 & Bradford \\
\hline grób 37 & dziecko infans I & 9,2 & $-17,1$ & 15,5 & 42,4 & 3,2 & Bradford \\
\hline grób 38 & dziecko infans I & 10,8 & $-18,4$ & 15,3 & 41,6 & 3,2 & Bradford \\
\hline grób 39 & dziecko infans I & 9,7 & $-18,0$ & 14,6 & 40,9 & 3,3 & Bradford \\
\hline grób 40 & dziecko infans I & 11,8 & $-18,1$ & 15,2 & 42,2 & 3,2 & Bradford \\
\hline grób 49 & dziecko infans I & 9,8 & $-18,1$ & 15,1 & 41,7 & 3,2 & Bradford \\
\hline grób 57 & dziecko infans I & 8,4 & $-18,3$ & 15,7 & 43,2 & 3,2 & Bradford \\
\hline grób 69 & kobieta adultus & 9,8 & $-17,7$ & 15,4 & 42,2 & 3,2 & Bradford \\
\hline grób 71 & dziecko infans II & 10,1 & $-17,6$ & 14,7 & 40,8 & 3,2 & Bradford \\
\hline \multicolumn{8}{|l|}{ Sowinki, stan. 23A } \\
\hline grób 148 & nieokreślona juvenis & 11,1 & $-17,3$ & 15,3 & 42,2 & 3,2 & Bradford \\
\hline grób 151 & nieokreślona juvenis & 10,8 & $-16,5$ & 15,9 & 43,7 & 3,2 & Bradford \\
\hline
\end{tabular}

Badania zostały wykonane w Stable Isotope Facility, University of Bradford; Kałdus badania Laurie Reitsemy wykonane w Stable Biogeochemistry Laboratory, Ohio State University.

Uzyskane wyniki wykazały, że dieta przebadanych osób należących do elit społecznych państwa wczesnopiastowskiego była w dużej mierze oparta na pożywieniu 
pochodzenia lądowego. Obejmowała rośliny typu $\mathrm{C}_{3}$ (zboża, warzywa, owoce) i produkty zwierzęce (mięso, sery, jajka), ale prawdopodobnie zawierała również pewne ilości ryb, szczególnie dwuśrodowiskowych (np. jesiotra). Przeprowadzone badania wykazały również, że dieta dorosłych osób pochowanych w przebadanych grobach komorowych (Bodzia, Dziekanowice, Kałdus, Pień, Sowinki) istotnie statystycznie różniła się od reszty społeczeństwa wczesnośredniowiecznej Polski (populacje porównawcze z Giecza, Gruczna i Kałdusa). W porównaniu do osób ze zwykłych grobów osoby o wysokim statusie społecznym pochowane w grobach komorowych miały o $1,7 \%$ o wyższe wartości $\delta^{13} \mathrm{C}$ (test Manna-Whitneya $\mathrm{U}=244,5, \mathrm{p}<0,001$ ) i o $0,8 \%$ o wyższe wartości $\delta^{15} \mathrm{~N}$ (test $\mathrm{t}$-Welcha $\mathrm{t}=-4,04, \mathrm{df}=16,1, \mathrm{p}=0,001$ ) (ryc. 3).

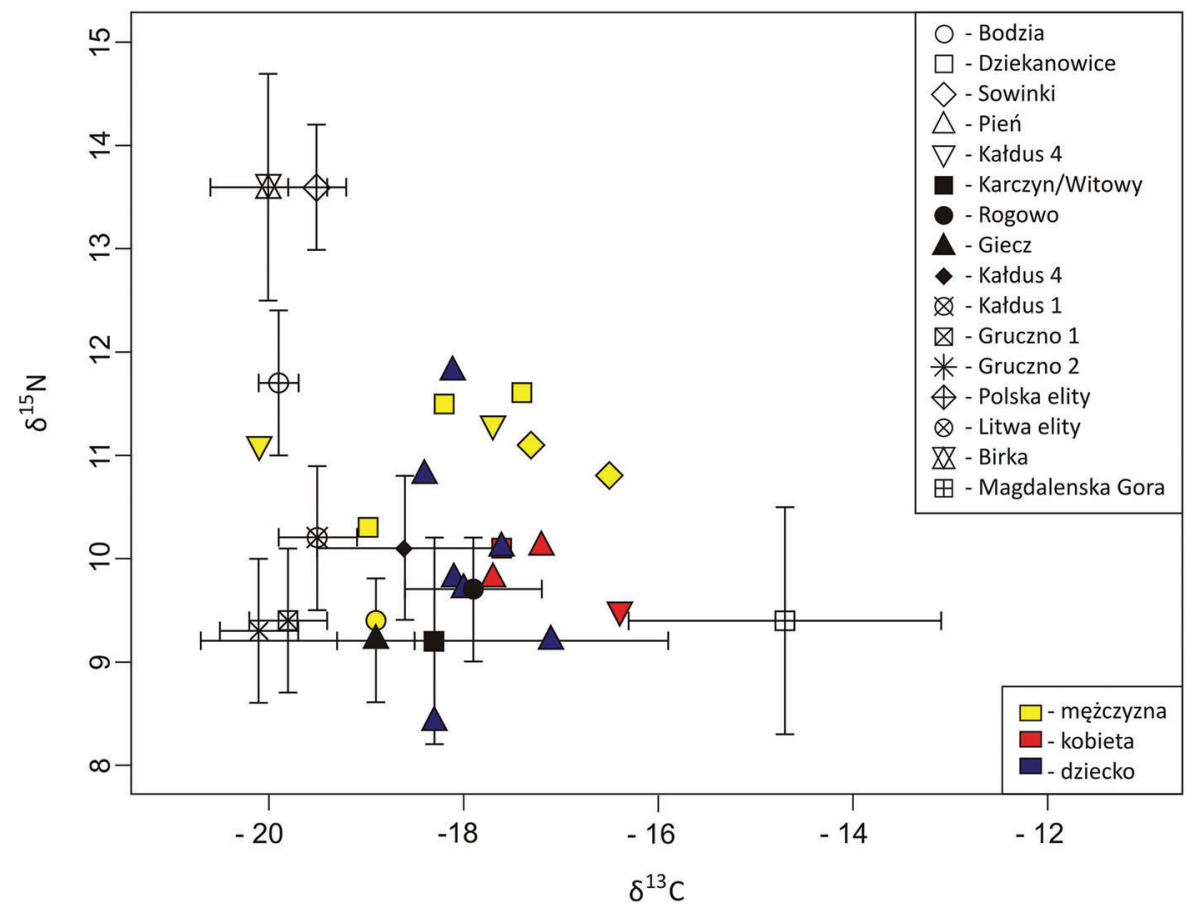

Ryc. 3. Wartości $\delta^{13} \mathrm{C}$ i $\delta^{15} \mathrm{~N}$ w kolagenie kostnym osób pochowanych w badanych grobach komorowych z obszaru państwa wczesnopiastowskiego na tle innych populacji ludzkich o zróżnicowanej diecie; oprac. R. Fetner 
Szczególnie dieta mężczyzn pochowanych w grobach komorowych różniła się od reszty społeczeństwa wczesnośredniowiecznego, zamieszkującego państwo pierwszych Piastów. Nie była ona jednak jednolita - można wyróżnić trzy grupy różniące się pod względem spożywanego pokarmu. Mężczyźni pochowani w grobach D162 w Bodzi i 20 w Dziekanowicach mieli dietę opartą na organizmach lądowych, przede wszystkim roślinach cyklu $\mathrm{C}_{3}$ (zboża, warzywa i owoce) z udziałem produktów zwierzęcych w tym mięsa. W odniesieniu do mężczyzny z Dziekanowic można stwierdzić, że w związku z wyższą w jego przypadku wartością azotu (10,3\%o wobec 9,4\%o) spożywana przez niego dieta była najprawdopodobniej bogatsza w białka zwierząt lądowych. Ogólnie dieta obu mężczyzn nie odróżniała się w istotny sposób od pożywienia osób z wczesnośredniowiecznych populacji porównawczych z ziem polskich pochowanych w zwykłych grobach. Dieta mężczyzny z grobu D162 była bliska zwyczajom żywieniowym populacji z Giecza, natomiast mężczyzny z grobu 20 - populacji z Kałdusa (ryc. 3).

Dietę znacząco odróżniającą się od stosowanej przez zwykłych członków populacji mieli natomiast mężczyźni pochowani w grobach II i 61 z Dziekanowic, 13A z Kałdusa oraz 148 i 151 w Sowinkach. Ich dieta była oparta na konsumpcji roślin $\mathrm{C}_{3}$ zapewne $\mathrm{z}$ jakimś udziałem roślin $\mathrm{C}_{4}$ (proso). Była ona bogata w proteiny zwierzęce pochodzące z mięsa zwierząt lądowych oraz ryb dwuśrodowiskowych takich jak np. jesiotr (Acipenser sturio) i być może morskich (ryc. 3). Jesiotr był rybą cenioną $\mathrm{w}$ średniowieczu, a jego konsumpcja $\mathrm{w}$ tym okresie jest poświadczona znaleziskami archeologicznymi (m.in. w Kałdusie, Napolu, Gnieźnie, Grzybowie, Gieczu, na Ostrowie Lednickim). W średniowieczu gatunek ten występował w przybrzeżnych wodach Bałtyku i większych rzekach uchodzących do tego morza. W wyniku nadmiernych połowów zaczął on od późnego średniowiecza zanikać, aż do całkowitego wytrzebienia w czasach nowożytnych. Jak wykazały badania Daniela Makowieckiego, istniało zróżnicowanie konsumpcji poszczególnych gatunków ryb w zależności od statusu społecznego, co jest widoczne w zróżnicowanej obecności ich szczątków w zależności od typu osiedla i zamieszkującej go ludności. W grodach reprezentowane były przede wszystkim szczątki jesiotra, szczupaka, suma, ryb karpiowatych oraz mniej licznie szczątki innych ryb, w tym okonia. Z kolei w materiałach z osad i podgrodzi najliczniej występowały szczątki ryb karpiowatych, a dopiero w dalszej kolej-

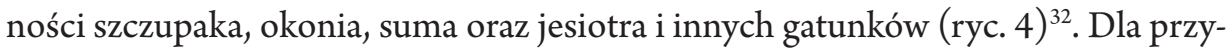
kładu w przypadku zespołu osadniczego na Ostrowie Lednickim udział szczątków 
jesiotra w materiałach z grodu wynosił $50 \%$, a na podgrodziu $35 \%{ }^{33}$. Spożywanie ryb z jednej strony było zapewne związane z walorami smakowymi, z czego wynikało zaliczanie ryb do dań wykwintnych, z drugiej strony mogło się wiązać z wypełnianiem obowiązujących $\mathrm{w}$ chrystianizmie postów, przestrzeganych w pierwszej kolejności przez elity kościelne i dworskie ${ }^{34}$. Można zatem przyjąć, że spożywanie wybranych gatunków ryb, w tym jesiotra, znamionowało status społeczny konsumentów. Co ciekawe, dieta średniowiecznej elity państwa wczesnopiastowskiego różniła się od diety późnośredniowiecznych i wczesnonowożytnych elit państwa polsko-litewskiego, pomimo że również ona zawierała istotny komponent w postaci ryb, ale innych gatunków i raczej słodkowodnych (ryc. 3).

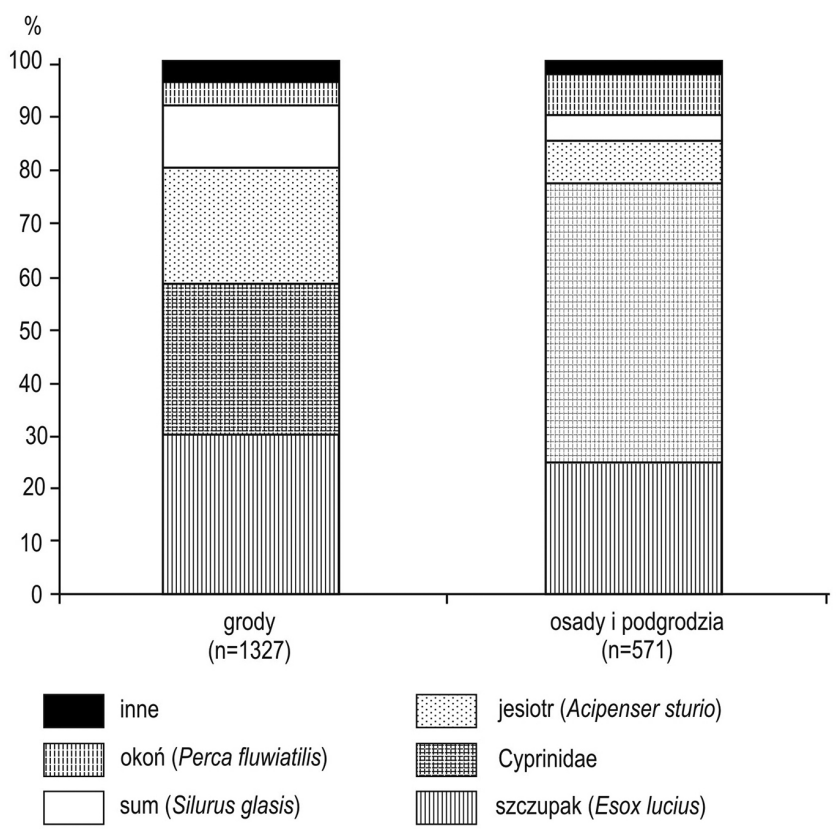

Ryc. 4. Procentowy udział szczątków ryb z wczesnośredniowiecznych grodów oraz osad i podgrodzi z obszaru Wielkopolski i Kujaw; za D. Makowiecki, Historia ryb i rybołówstwa w holocenie na Niżu Polskim w świetle badań archeoichtiologicznych, Poznań 2003, oprac. B. Bednarczyk

Od pozostałych mężczyzn pochowanych w grobach komorowych z obszaru państwa pierwszych Piastów istotnie rodzajem swojej diety odróżniał się mężczyzna

33 Tenże, Some remarks on medieval fishing, s. 30.

34 Tamże, s. 131. 
złożony w grobie 60 na cmentarzysku w Kałdusie (ryc. 3, 5). Jego dieta była oparta na pożywieniu składającym się z roślin cyklu $\mathrm{C}_{3}$ i produktów zwierzęcych, być może z pewnym udziałem ryb słodkowodnych. Nie zawierała w swoim składzie ani prosa, ani mięsa ryb dwuśrodowiskowych czy morskich, była natomiast zbliżona do diety elit litewskich z XV-XVIII w. (ryc. 8, 14).

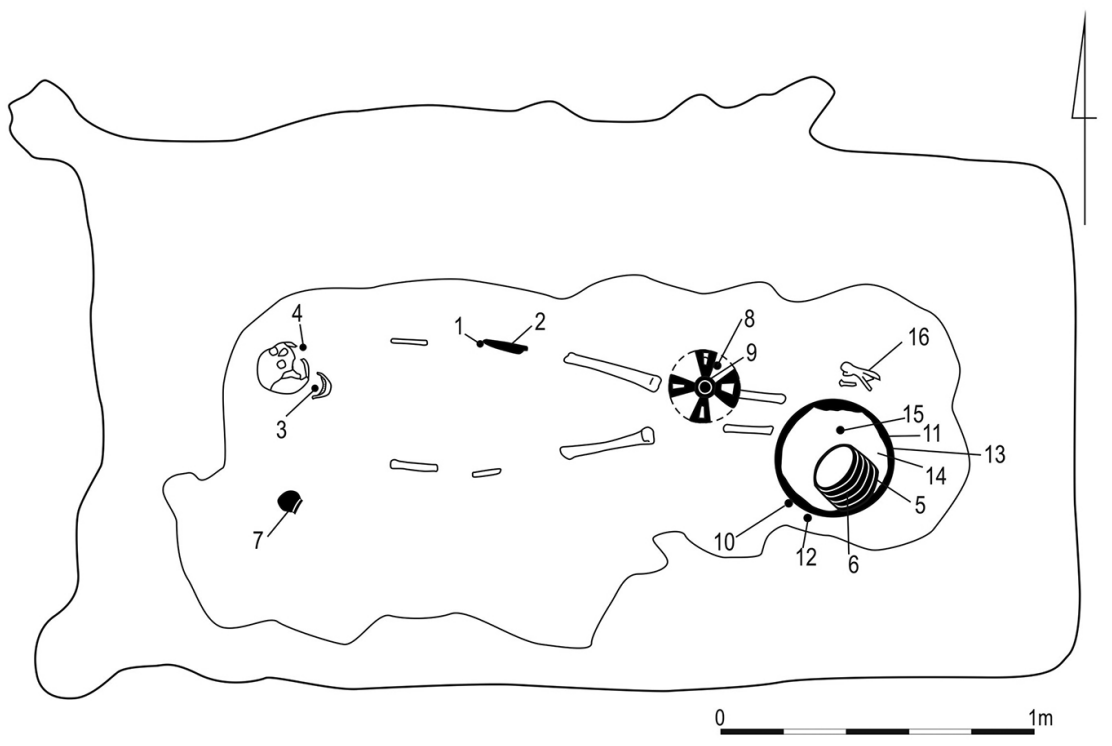

Ryc. 5. Kałdus, stan. 4, plan grobu komorowego 60, mężczyzna, adultus/maturus 1: złoty drucik (oplot z rękojeści noża), 2: dwa żelazne noże w pochewce z brązowym okuciem, 3: brązowa skuwka, 4: fragment srebrnej monety, 5: brązowa misa, 6: wiaderko okute żelazną blachą, 7: żelazna zapinka, 8: drewniana misa, 9: drewniany kubek, 10: fragment włókna łykowego ?, 11 : fragment skórzanego buta, 12: łupina orzecha laskowego, 13: fragment tkaniny, 14: fragment toczonego drewnianego talerza ?, 15: fragmenty trzech rodzajów tkanin, 16: kości świńskiej łopatki zlokalizowane w obrębie owalnego negatywu (przy misie brązowej); za Wczesnośredniowieczne cmentarzysko szkieletowe w Kałdusie (stanowisko 4), red. W. Chudziak (Mons Sancti Laurentii, t. 5), Toruń 2010 z modyfikacjami, oprac. B. Bednarczyk

Tabela 4. Wyniki badań izotopów węgla i azotu przedstawicieli elit społecznych pochowanych w grobach komorowych - Bodzia, Dziekanowice, Kałdus, Pień, Sowinki

\begin{tabular}{|l|c|c|c|c|c|}
\hline \multicolumn{1}{|c|}{ Stanowisko } & Próba & $\boldsymbol{\delta}^{15} \mathbf{N} \%$ ó & Średnia \%o & $\boldsymbol{\delta}^{13} \mathbf{C} \%$ & Średnia \%o \\
\hline dorośli & 13 & $9,4-11,6$ & $10,5 \pm 0,8$ & $-20,1--16,4$ & $-17,7 \pm 1,1$ \\
\hline mężczyźni & 9 & $9,4-11,6$ & $10,8 \pm 0,7$ & $-20,1--16,5$ & $-18,0 \pm 1,2$ \\
\hline
\end{tabular}




\begin{tabular}{|l|c|c|c|c|c|}
\hline kobiety & 4 & $9,5-10,1$ & $9,9 \pm 0,3$ & $-17,6--16,4$ & $-17,7 \pm 0,6$ \\
\hline dzieci & 7 & $8,4-11,8$ & $10,0 \pm 1,1$ & $-18,4--17,1$ & $-17,9 \pm 0,4$ \\
\hline
\end{tabular}

Dieta kobiet pochowanych w grobach komorowych częściowo różniła się od diety mężczyzn złożonych w tego typu obiektach (tab. 4; ryc. 3). O ile wartości $\delta^{13} \mathrm{C}$ nie wykazują istotnych statystycznie różnic (test $\mathrm{t}$-Welcha $\mathrm{t}=-1,46, \mathrm{df}=10,7$, $\mathrm{p}$-value $=0,172$ ), to sygnatury izotopowe $\delta^{15} \mathrm{~N}$ różnią się i mają wyższe wartości dla mężczyzn (test $\mathrm{t}$-Welcha $\mathrm{t}=3,69, \mathrm{df}=10,9, \mathrm{p}=0,004$ ).

Dieta kobiet pochowanych w grobach komorowych miała charakter mieszany i była oparta na konsumpcji roślin cyklu $\mathrm{C}_{3} \mathrm{i}_{4}$ (proso) z udziałem produktów zwierzęcych. Kobiety miały jednak w swojej diecie mniej protein zwierzęcych pochodzących z mięsa zwierząt lądowych i ryb, czyli ich dostęp do tego typu pożywienia był zapewne mniejszy. Różnica w wartości $\delta^{15} \mathrm{~N}$ między mężczyznami a kobietami wynosi $0,9 \%$ o (10,8\%o dla mężczyzn wobec 9,9\%o dla kobiet) (tab. 4). Kobieta z grobu 62 w Dziekanowicach miała identyczną dietę jak osoba w wieku infans II, być może dziewczynka, z grobu 71 w Pniu. Z kolei dieta kobiety pochowanej w grobie 13AB w Kałdusie odznaczała się mniejszą konsumpcją produktów zwierzęcych i większym udziałem prosa oraz prawdopodobnie brakiem ryb. Przy tym wartości $\delta^{13} \mathrm{C}$ i $\delta^{15} \mathrm{~N}$ zarejestrowane w kolagenie jej kości istotnie różniły się od takich wartości w szkielecie pochowanego z nią mężczyzny (kobieta $\delta^{15} \mathrm{~N} 9,5 \%$, $\delta^{13} \mathrm{C}-16,4 \%$, mężczyzna $\delta^{15} \mathrm{~N}$ $11,3 \%$ o, $\delta^{13} \mathrm{C}-17,7 \%$ ) (tab. 3, ryc. 6). Wskazuje to na różnice w spożywanej diecie obu tych osób, przy czym dieta tego mężczyzny była bogatsza w proteiny zwierzęce, w tym zapewne ryby (wartość $\delta^{15} \mathrm{~N}$ mężczyzny była wyższa o 1,8\%o niż kobiety).

Dieta dzieci w różnym wieku, pochowanych w grobach komorowych (Pień groby $37,38,39,40,49,57$ i 71), była również zróżnicowana i generalnie bliższa diecie kobiet niż mężczyzn złożonych w tego typu obiektach (tab. 2, 3; ryc. 3). Wartość $\delta^{15} \mathrm{~N}$ wskazuje na to, że około dwuletnie dziecko z grobu $40 \mathrm{w}$ Pniu było karmione piersią $\left(\delta^{15} \mathrm{~N} 11,8 \%\right.$ ), natomiast około trzyletnie dziecko z grobu 38 prawdopodobnie ciągle jeszcze było karmione piersią $\left(\delta^{15} \mathrm{~N} 10,8 \%\right.$ o), ale spożywało już stały pokarm. Dzieci z pozostałych grobów $(37,39,49,57,71)$ w wieku od 4 do 13 lat miały podobną dietę jak osoby dorosłe (wartość $\delta^{15} \mathrm{~N}$ między 8,4 a 11,8\%o, wartość $\delta^{13} \mathrm{C}$ między - 18,4 a - 17,1\%o), przy czym dieta około czteroletniego dziecka z grobu 57 zawierała stosunkowo mało protein (wartość $\delta^{15} \mathrm{~N} 8,4 \%$ ) (tab. 3, 4, ryc. 3). 


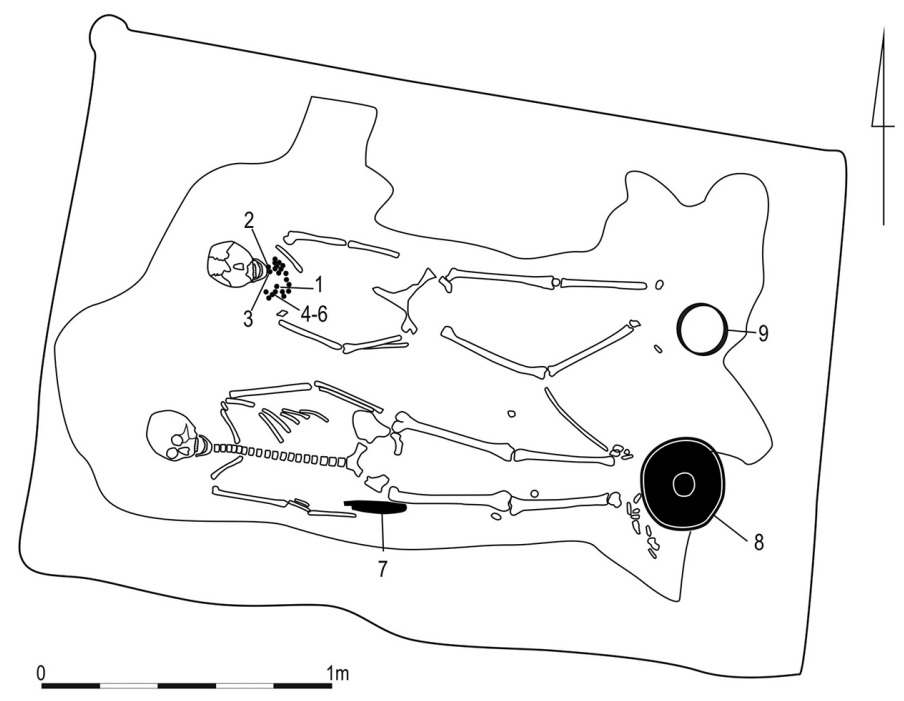

Ryc. 6. Kałdus, stan. 4, plan grobu komorowego 13AB, A - mężczyzna, adultus; B - kobieta, adultus: 1: srebrne kaptorgi, 2: srebrna klamra, 3: srebrny paciorek, 4-6: paciorki z kryształu górskiego, karneolu i nieokreślonego surowca, 7: dwa żelazne noże w pochewce z brązowym okuciem, 8: brązowa misa, 9: wiaderko z żelaznym okuciem; za Wczesnośredniowieczne cmentarzysko szkieletowe w Katdusie (stanowisko 4), red. W. Chudziak (Mons Sancti Laurentii, t. 5), Toruń 2010 z modyfikacjami, oprac. B. Bednarczyk

\section{Podsumowanie}

Badania diety oparte na analizie trwałych izotopów węgla i azotu szczątków kostnych osób pochowanych w grobach komorowych wykazały, że dieta osób będących przedstawicielami elit państwa wczesnopiastowskiego różniła się od pożywienia reszty społeczeństwa. Dotyczyło to szczególnie mężczyzn pochowanych w tego typu grobach, chociaż nie wszystkich. Wysokie wartości azotu $\delta^{15} \mathrm{~N}(9,4-11,6 \%$, średnia 10,5 $\pm 0,8 \%$ o odpowiadające w sieci troficznej organizmom wszystkożernym i mięsożernym, wskazują na dietę bogatą w proteiny zwierzęce, zapewne w postaci mięsa. Jest ona znacznie wyższa niż w średniowiecznych populacjach porównawczych (Giecz, Gruczno, Kałdus) i porównywalna z wartościami uzyskanymi dla wczesnonowożytnych elit litewskich Rzeczpospolitej Obojga Narodów. Korelacja 
wysokich wartości węgla i azotu może wskazywać na to, że w skład tej diety wchodziły również ryby, przede wszystkim dwuśrodowiskowe (takie jak np. jesiotr) i/ lub mięso zwierząt domowych karmionych prosem. Nie jest również wykluczone, że wysokie wartości $\delta^{13} \mathrm{C}$ mogą być wynikiem picia przez te elity znacznych ilości piwa wytwarzanego z prosa.

Brak większych różnic $\mathrm{w}$ diecie $\mathrm{w}$ stosunku do reszty populacji stwierdzono w przypadku dwóch mężczyzn pochowanych w grobach komorowych $\mathrm{z}$ cmentarzyska w Bodzi i Dziekanowicach. Warto przy tym zauważyć, że dieta członków elit wczesnośredniowiecznych różniła się od przedstawicieli elit późnośredniowiecznych państwa polsko-litewskiego. Bliższa im była tylko dieta mężczyzny z grobu 60 w Kałdusie, która z kolei znacząco różniła się od diety pozostałych mężczyzn pochowanych we wczesnośredniowiecznych grobach komorowych.

Z kolei kobiety pochowane w tego typu grobach miały dietę inną niż mężczyźni, bliższą reszcie populacji i bardziej podobną do diety populacji z okresu rzymskiego. Nie była ona tak bogata w proteiny zwierzęce jak dieta mężczyzn i zawierała więcej produktów roślinnych, w tym prosa. Dzieci miały dietę podobną do kobiet, przy czym jedno z nich, dwuletnie, było jeszcze karmione piersią, a kolejne było w okresie przejścia pomiędzy karmieniem piersią a dietą charakterystyczną dla dorosłych.

\section{Podziękowania}

Autorzy dziękują Andrew Gledhillowi z University of Bradford za przygotowanie próbek do badań i wykonanie pomiarów, Rafałowi Fetnerowi z Wydziału Archeologii Uniwersytetu Warszawskiego za wykonanie testów statystycznych oraz Annie Gręzak z Wydziału Archeologii Uniwersytetu Warszawskiego za oznaczenie gatunków zwierząt. Dziękujemy także Recenzentom za wszystkie uwagi poczynione do tekstu.

Badania zostały sfinansowane ze środków Narodowego Centrum Nauki przyznanych w ramach finansowania stażu po uzyskaniu stopnia naukowego doktora na podstawie decyzji nr DEC-2013/08/S/ HS3/00178.

Nadesłany: 24 VII 2020

Nadesłany po poprawkach recenzyjnych: 16 II 2021

Zaakceptowany: 17 II 2021 
Dr Dariusz Błaszczyk

Katedra Archeologii Średniowiecza i Nowożytności, Wydział Archeologii, Uniwersytet Warszawski

ul. Krakowskie Przedmieście 26/28

00-927 Warszawa

d.blaszczyk@uw.edu.pl

Dr Alicja Drozd-Lipińska

Katedra Biologii Człowieka, Wydział Nauk Biologicznych i Weterynaryjnych, Uniwersytet Mikołaja Kopernika w Toruniu

ul. Lwowska 1, 87-100 Toruń

turdus@umk.pl

Mgr Andrzej Krzyszowski

Muzeum Archeologiczne w Poznaniu, Dział Archeologii Wielkopolski

ul. Wodna 27, 61-781 Poznań

andrzejkrzyszowski@wp.pl

Dr hab. Dariusz Poliński, prof. UMK

Katedra Średniowiecza i Czasów Nowożytnych, Instytut Archeologii, Uniwersytet Mikołaja Kopernika w Toruniu

Szosa Bydgoska 44/48, 87-100 Toruń

dariusz.polinski@umk.pl

Mgr Anna Wrzesińska

Muzeum Pierwszych Piastów na Lednicy, Pracownia Antropologiczna

Dziekanowice 23, 62-261 Lednogóra

anna.wrzesinska@lednicamuzeum.pl

Mgr Jacek Wrzesiński

Muzeum Pierwszych Piastów na Lednicy, Oddział Rezerwat Archeologiczny Gród w Grzybowie

Grzybowo 10A, 62-300 Grzybowo

jaled@wp.pl

\section{Resume}

Analyses of stable carbon and nitrogen isotopes in bone collagen were made for the remains of individuals from the early medieval cemeteries at Bodzia (grave D162), Dziekanowice (graves II, 20, 61, 62), Pień (graves 32, 37, 38, 39, 40, 49, 57, 69, 71) and Sowinki (graves 
$148,151)$. In addition, the results of an analysis made by Laurie Reitsema for material samples from Kałdus (graves $13 \mathrm{AB}$ and 60 ) were used. The samples were taken from the ribs. In total, the analysis was carried out for 19 individuals buried in chamber graves, including 8 men, 4 women and 7 children.

The obtained results have showed that the diet of the analysed individuals, members of a social elite of the early Piast state, was largely based on food of land origin. It included $\mathrm{C}_{3}$ plants (cereals, vegetables, fruit) and animal products (meat, cheeses, eggs) but probably also contained some amounts of fish, especially anadromous ones (e.g. sturgeon). The research also showed that the diet of adults buried in the examined chamber graves, differed significantly from the rest of the society in early medieval Poland (comparative populations from Giecz, Gruczno and Kałdus). First of all, it was richer in animal proteins, probably in the form of meat. Also, the diets of men and women buried in the chamber graves varied, wherein the diets of men were better.

Ttumaczenie: Dariusz Błaszczyk 